MATTHEW GAVIN FRANK

\title{
RITUAL, I WANT MY BLOOD TO BE USED IN A
}

1 .

We wake again to swallows and all creatures who make verbs of their names. Swallows swallowing. Worms worming. Grasshoppers grasshopping. Louisa and I slept well last night, and today we have designs on Monte Albán, Oaxaca, Mexico's pre-Columbian archeological site and once the Zapotec center for all things sociopolitical, economic, gory, and gustatory.

Before we leave the bed, Louisa, watching a family of ants blossom along the ceiling, says, "I want my blood to be used in a ritual."

The streets are quiet, bone-bare as we make our way toward Avenida Mina and the bus that promises to take us to Monte Albán.

A sign of something perhaps sacrificial appears as we hang a right onto Avenida Mina-a short man whose single gold tooth and pencil mustache tell us to cross the street opens his arms as we approach. His black guayabera, the shoulders adorned with skulls clutching roses in their teeth, has not a single button fastened, and it blows behind him like a cape, his middleaged skin drooping. His hair shines with oil, and his torso bears a vertical scar from sternum to belly button and a horizontal one that joins, in uncanny symmetry, his nipples. Over this surgical crucifix he has tattooed, in a garish display of either piety or joke, an image of Jesus dying, replete with eyes rolling back and failing mouth.

We see the small van behind him painted with a blocky Zapotec temple and the nest of photocopied pamphlets clutched into his fist. In the sound of the asthmatic engine, all expectation reverses itself, confused, inverts like a name wondering why, in order to be considered "official," it must be rendered last name, comma, first.

Before he can say, in a high-pitched, lisping voice, Monte Albán? Monte Albán? Louisa and I are already drawn to him, and she asks me, Our ride?

As he opens his mouth, gold tooth reflecting the sun downward into the eyes of Ink Jesus on Scar Cross, Louisa and I step toward him and, in reception of ride or ritual, open our arms too. 
2.

Conspiracies:

1954: June. Richard Case Nagell, before becoming a double agent in the CIA (which some believe earned him the code name "Mister X"), is the sole survivor of a plane crash. After waking from his coma, he cites his superior parachuting skills as responsible for his life.

1988: The superior parachuting skills of R. Robert Robbins of the American Astronomical Society allowed him to obtain new measurements that show previously unsuspected astronomical alignments built into the Zapotec temples at Monte Albán, Mexico. These include “...a functioning solar ceremonial center used to celebrate equinox and solstice positions of the sun. Further, new sightlines... point out an additional group of stars of interest to this culture in $250 \mathrm{BC} .$. . There are two additional lines of argument suggesting that this is not merely coincidental. (1) The new stars have a highly suggestive, symmetric geometrical relationship with other stars known to be of importance to this culture, and (2) these new stars lead to an identification of one of the unknown constellation groupings on the famous Aztec calendar stone."

Circa 500 BC: Monte Albán is founded by a group of enterprising Zapotecs who quickly establish it as the early capital of the Oaxacan highlands.

1963: Nagell travels to Mexico in order to distribute Marxist propaganda.

Circa 500 BC: Said enterprising Zapotecs name their capital Danipaguache, or "Sacred Life Hill," which the Spanish later rename Monte Albán-White Mountain or Dawn Mountain. Either way, the elevation means that they are living closer to the sky and, in turn, the gods.

1954: November 28. Just after Thanksgiving, Nagell crashes yet another plane. Once again, he is the sole survivor, but sustains "a permanent depression on the left side of his head and organic brain damage." His psychiatrist, Dr. Edwin Weinstein, declares that, as a result of this accident, Nagell's "judgment and perception of reality was seriously disturbed so that he could not accurately distinguish right from wrong." Soon after emerging from his coma, Nagell recalls seeing a strange "grouping" of stars just before the plane went down. This recollection is dismissed as a confused muttering. In the National Museum of Anthropology in Chapultepec Park, Mexico City, the Aztec calendar stone sits behind its glass case.

Circa 500 BC: Over the course of two thousand years, both Zapotecs and their conquerors, the Mixtecs, have added their architectural flights of fancy 
to the ancient capital of Monte Albán, including the construction of two ball courts. The precise rules of the ancient ball game (which the Aztecs called ullamaliztli) are up for grabs (some historians believe racquetball is a descendant). These games were often attended by human sacrifice-sometimes of the captain of the losing team. According to ancient panel depictions, the head of this captain was caved in with the heavy stone ball, leading, as was the case with Nagell's second plane crash some twenty-four hundred years later, to a seriously disturbed perception of reality, before being cut off. Certain historians believe that this decapitated head was then, during game number two, used as the ball.

770 AD: Monte Albán is abandoned.

1954: The Triple Tomb of Yagul (a center settled at the beginning of the Monte Albán period, which flourished only after Monte Albán was abandoned) is first excavated. Archeologists believe the tomb had been looted in pre-Hispanic times. As such, as a direct result of this looting, rumors of the Triple Tomb's curse abound, associating a rash of head injuries, randomly delivered by the gods, with the excavation. At the moment the shovels penetrate the tomb, Nagell's plane, many sky-miles away, goes down.

1770: Exactly one thousand years after the abandonment of Monte Albán, James Kennedy, popularly cited as the first patriarch of the traceable "modern" Kennedy family tree, is born.

1954: December 25. On Christmas Day, Nagell, suffering from the plane crash aftereffects of the Triple Tomb curse, is granted his first conscious memory. Quietly, he laments the Washington Senators' losing baseball season. Lee Harvey Oswald, fifteen years old, joins the Astronomy Club of New Orleans due to both his desire "to infiltrate" and search for "unknown constellations."

1963: June. The CIA assigns Nagell, less than ten years after his formative crash, to establish a relationship with a man about whom the agency is becoming increasingly curious. This is Lee Harvey Oswald, who, by this point, having failed in discovering any new stars, has discovered instead a different line of work.

1963: August. Nagell meets with Oswald, who, according to Nagell's later letter to Senator Richard Russell, he was supposed to kill "if it looked like things were going to progress beyond the talking stage."

1963: August. Nagell does not kill Oswald. Instead, he flees to Mexico City, where, as is typical of those with double-agent status, he gets in touch with 
his Soviet contact, who also wants Oswald dead. Nagell knows this contact only by his code name, "Oaxaca."

963: With Monte Albán abandoned, many Mixtec centers and fringe Zapotec settlements-exactly one thousand years before Nagell (in Mexico City) is again ordered by "Oaxaca" to assassinate Lee Harvey Oswald—begin a sixteen-year "great" war known as the War of Heaven. During this war, the Zapotec city-state of Yagul, replete with Triple Tomb, emerges.

1950: JFK is elected to his third term in the House. The paranoia of McCarthyism begins after Joseph McCarthy announces he has a list of Communist affiliates working in the State Department. Nagell first studies Russian at Fort Bragg. Various astronomical "ceramic phases" are discovered and defined along Monte Albán's North Platform. Regulus, the brightest star in the constellation Leo is discovered, along with its companion (reputed to be a white dwarf). Three hundred and fifty times brighter than the sun, and due to its rate of speed and spin, Regulus is nicknamed the Bullet Star.

1963: November 22. Just before Thanksgiving, Nagell sits in an El Paso, Texas, jail cell, convicted (he maintains wrongfully) for robbing a bank after mailing plane tickets and five hundred dollars to Mexico City (reportedly either for Oswald or "Oaxaca" to pick up), and, thirteen years after the discovery of the Bullet Star and precisely one thousand years after the War of Heaven began, JFK sustains the "organic brain damage" that kills him.

1973: Exactly ten years later, Louisa is born.

1930: The first "large-scale" excavations at Monte Albán are assigned to archeologist Alfonso Caso y Andrade, who uncovered the monument that has become known as Tomb Seven. The tomb housed various jewels and precious metals, which are believed to have been offerings to the gods. These offerings were then "looted" and sent to the Regional Museum of Oaxaca, stirring speculation of a curse similar to that of the Triple Tomb. Richard Case Nagell, at the moment the decrepit shovel first penetrated Tomb Seven in Monte Albán, bathing it in daylight for the first time in centuries, is born.

1917: At approximately the same time that astronomer Heber Curtis discovers a new star in the Spiral Nebula NGC 4527, the Golden Age of Mexican Archeology begins with Manuel Gamio, who is succeeded in 1930 by Alfonso Caso. Various revolutionary methods are used to make important discoveries, among which include numerous tombs and their ancient offerings. As Heber first hypothesizes that spiral nebulae are actually independent galaxies, known as "island universes," Gamio commissions painter Francisco 
Goitia as a consultant on the early discovered art. Inspired by the ancient works, Goitia paints his famous piece, The Hanged Man, which he finishes on the morning of May 29, a Tuesday. Four hours later, at approximately 3:00 p.m., John F. Kennedy is born in Brookline, Massachusetts.

1920: Heber Curtis engages fellow astronomer Harlow Shapley in an argument concerning the essence of spiral nebulae and the size of the universe. It is known as the Great Debate. JFK turns three.

1970: Fifty years later, in Oaxaca, the campesinistas (agrarian populists) engage the proletaristas (proletarians) in an argument over the role of the peasantry. This argument, which has been described as "Marxist" in nature, is also known as the Great Debate.

1961: Willis Shapley, Harlow Shapley's son, works as a researcher for JFK on space exploration. His research provided the basis for Kennedy's speech that year in which he declared that America has the goal "before this decade is out, of landing a man on the moon and returning him safely to Earth." Nagell, soon after listening to the speech, separates from his wife and travels to Mexico City, where he is invited to attend a reception at the Soviet 60 Embassy.

1917: As Kennedy gasps his first infant breaths, Heber Curtis also discovers twelve novae, defined as "cataclysmic nuclear explosions caused by the accretion of hydrogen onto the surface of a white dwarf star," which is, of course, the Bullet Star's celestial companion.

Sometime after 1995: The Museum of Texas Tech University's Educational Division publishes the "Amazing Astronomy" Teacher's Manual, which, among other celestial nuggets, defines white dwarf star ("an old, extremely dense star about as large as the earth but with the mass of the sun and is no longer fusing lighter elements into heavier ones"), and cites as its sources both R. Robert Robbins, the Monte Albán "parachuting astronomer," and the John F. Kennedy Space Center.

1995: November. Just before Thanksgiving, Nagell dies of heart disease in Los Angeles. During the weeks preceding his death, corrupt land developers, violating the Monte Albán boundary agreement of 1994, attempt to sell plots of land that belong to the sacred site. Louisa sits at her Old Mutual corporate cubicle in Johannesburg, South Africa, under the fluorescent lights. Bored, she envisions a pyramid, which she confuses for the Egyptian variety.

2009: Pulling into Monte Albán, Ink Jesus with Scar Cross ringing the steering wheel's neck, sweat in my eyes, and blaring radio music in my ears, 
Louisa confesses, leaning into my ear with an inhale bordering on panic, that her 1995 "pyramid" vision closely resembled the crumbling structure on Monte Albán's North Platform, known today only as Edificio Equis. Building $\mathrm{X}$. It being daylight, the known and unknown stars, for the time being at least, keep their comments to themselves. 